\title{
Hydrothermal alteration of sediments in the high-temperature reaction zone at Central Hill of Escanaba Trough, Gorda Ridge
}

\author{
Konstantin Galin ${ }^{1, *}$, Alexandra Khakhina ${ }^{1}$, Victor Kurnosov ${ }^{1}$, and Yurii Konovalov ${ }^{1}$ \\ ${ }^{1}$ Geological Institute of Russian Academy of Sciences, Moscow, Russia
}

\begin{abstract}
In sediments from Holes ODP 1038A and 1038H, drilled near the hot springs at Central Hill, Escanaba Trough (Gorda Ridge), redistribution of major elements occurs during the water-rock interaction. Contents of $\mathrm{Si}, \mathrm{Fe}, \mathrm{Mg}, \mathrm{Ca}, \mathrm{Na}$ and $\mathrm{K}$ have changed in altered sediments. In this process, an increase/decrease in contents of major elements in altered sediments shows a decrease/increase in their contents in fluids. The irregular distribution of major elements in altered sediments resembles a layer pie, which reflects the existence of lateral flows of hydrothermal fluids.
\end{abstract}

\section{Introduction}

The Escanaba Trough in the Gorda Ridge and the Middle Valley in the Juan de Fuca Ridge are the examples of spreading ridges in which deep-sea holes are drilled. In core valleys of these oceanic rifts, sediments with big layer thickness accumulate at high speed $(1200-2300 \mathrm{~m} / \mathrm{myr})$ and cover the hydrothermal systems. Escanaba Trough is covered by the Late Pleistocene interbedded hemipelagic sediments and turbidites $[1,2,3]$. The study of altered sediments from holes drilled at Central Hill, Escanaba Trough, was conducted together with the study of changes in the chemical composition of sediments from holes drilled in the "Dead Dog" hydrothermal field [Khakhina et al., this volume].

\section{Material and methods}

The Escanaba Trough of the Gorda Ridge (Fig. 1) is a slow-spreading of tectonomagmatic structure $(2.4 \mathrm{~mm} / \mathrm{yr})$ [4], in which the Central Hill is located with active hydrothermal vents (Fig. 2), where temperatures range from 108 to $217^{\circ} \mathrm{C}$ [3]. The Central Hill has $1 \mathrm{~km}$ in diameter and $60 \mathrm{~m}$ high in elevation [5]. At the latitude of the Central Hill, the Trough is filled with $\sim 600 \mathrm{~m}$ of sediments [6]. At Central Hill several holes were drilled at the ocean depth 3215 - $3254 \mathrm{~m}$ (Fig. 2). Holes 1038A and 1038H were selected for the study. They were drilled near the active hydrothermal vent $\left(217^{\circ} \mathrm{C}\right)$.

Hole 1038A was drilled to a depth of $114.5 \mathrm{~m}$, in a few meters from the vent with a temperature of $217^{\circ} \mathrm{C}$. Hole $1038 \mathrm{H}$ was also drilled next to this vent to a depth of $192.89 \mathrm{~m}$.

\footnotetext{
*Corresponding author: konsgalin@yandex.ru
} 
The sedimentary section at Central Hill is divided into several lithologic units [3]:

(I) Unaltered hemipelagic clay unit is not present at Site 1038.

(II) Interbedded fine-grained turbidites and hemipelagic muds: 1038A (interval 0.00-76.20

m), $1038 \mathrm{H}$ (interval 0.00-68.31 m).

(III) Sand-rich turbidites with minor hemipelagic muds: 1038A (interval 76.20-114.50 m), $1038 \mathrm{H}$ (interval 0.00-68.31 m).

(IV and V) Fine- to medium-grained sand turbidites interbedded with siltstone and claystone: $1038 \mathrm{H}$ (intervals $125.60-135.20$ and 144.90-154.90 m).

(VI) Carbonate altered silt to clay turbidites and hemipelagic muds: Hole $1038 \mathrm{H}$ (interval 183.60-192.80 m).

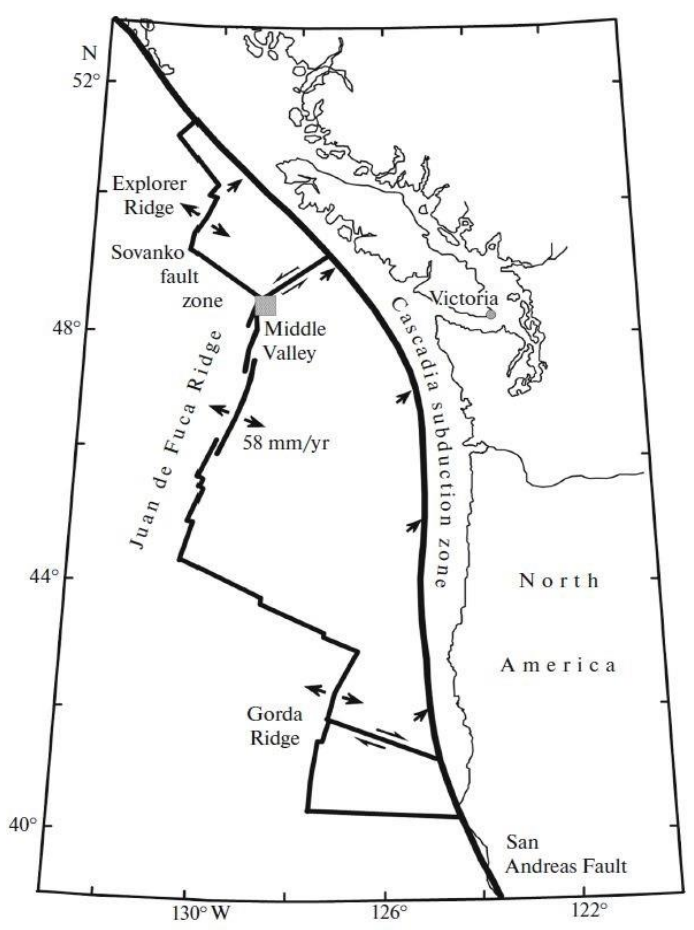

Fig. 1. The structural-tectonic scheme of the location of the Middle Valley of the Juan de Fuca Ridge; the arrows indicate plate motion [3].

At Central Hill, each sedimentary interval has been placed into an alteration facies [3]. Facies $a$ is defined as relatively unaltered primary sediment. It is not present at Holes $1038 \mathrm{~A}$ and $1038 \mathrm{H}$.

Facies $b$ contains authigenic carbonate nodules: Hole 1038A (interval 66.60-114.5 m) and Hole $1038 \mathrm{H}$ (interval $29.80-58.40 \mathrm{~m}$ ). Facies $\mathrm{c}$ is defined as clay-and chlorite-altered, noncalcareous sediments: 1038A (upper part of the sediment section, to a depth of $27.90 \mathrm{~m}$, Hole 1038H (intervals 2-29.89, 125.60-192.80 m).

Contents of major elements in sediments were determined by XRF method at the Geological Institute (Russian Academy of Sciences) coupled with methods of analytical chemistry for the separate determination of $\mathrm{Fe}_{2} \mathrm{O}_{3}, \mathrm{FeO}, \mathrm{CO}_{2}$, and $\mathrm{H}_{2} \mathrm{O}^{-}$. 


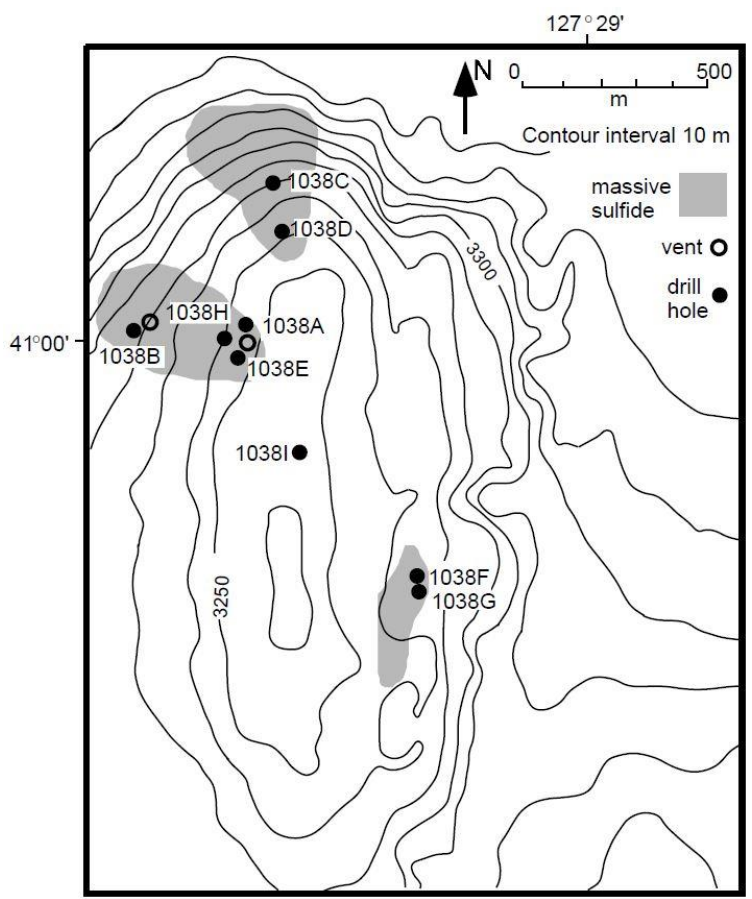

Fig. 2. Location map showing the holes drilled at Central Hill [3].

\section{Results and discussion}

In a Hole 1038A, Unit IIc, which is located in upper part of the sediments (to a depth of $27.90 \mathrm{~m}$ ) in altered sediments (Units $\mathrm{IIc}$, IIb and IIIb), the contents of $\mathrm{Si}, \mathrm{Ca}, \mathrm{Na}, \mathrm{K}$ decreased simultaneously while $\mathrm{Mg}$ content increased. The content of $\mathrm{Fe}_{\text {total }}$ decreased as well. In different Units II and III, attributed to one sediment facies (Facies $c$ ) change their the chemical composition (Table 1). Common is the content of $\mathrm{Si}, \mathrm{Ti}$, and $\mathrm{P}$ which is practically the same, compared with the contents of these elements in fresh sediments. At the same time, in Unit IIIb the contents of $\mathrm{Fe}_{\text {total }} \mathrm{Mn}, \mathrm{Mg}$, Na decrease while the contents of $\mathrm{Ca}$ and $\mathrm{K}$ increase in contrast to Unit IIb.

Table 1. Chemical composition of samples from the Hole 1038A.

\begin{tabular}{|c|c|c|c|c|c|c|c|c|c|}
\hline Sample & Si & Ti & Fetotal & Mn & Mg & Ca & Na & K & P \\
\hline $\begin{array}{c}3074 \\
\text { (IIc) }\end{array}$ & 17.1 & 0.74 & 8.46 & 0.08 & 2.6 & 0.36 & 0.72 & 0.02 & 0.10 \\
\hline $\begin{array}{c}3075 \\
\text { (IIb) }\end{array}$ & 25.6 & 0.56 & 5.00 & 0.09 & 2.74 & 2.30 & 2.22 & 1.18 & 0.15 \\
\hline $\begin{array}{c}3076 \\
\text { (IIIb) }\end{array}$ & 27.8 & 0.44 & 3.63 & 0.07 & 2.59 & 3.06 & 1.74 & 2.12 & 0.12 \\
\hline $\begin{array}{c}3077 \\
(\mathrm{IIIb})\end{array}$ & 31.9 & 0.37 & 2.67 & 0.05 & 1.82 & 2.44 & 2.42 & 1.51 & 0.12 \\
\hline
\end{tabular}

After the chemical composition of sediments (related to facies) correlation, a significant difference was found out in changes of $c$ (Unit IIc) and $b$ (Units IIb and IIIb). Changes that occurred in Unit IIc (decrease in the content of $\mathrm{Si}, \mathrm{Ca}, \mathrm{Na}, \mathrm{K}$, and increase in content of $\mathrm{Mg}$ and $\left.\mathrm{Fe}_{\text {total }}\right)$ did not appear in Units IIb and IIIb. 
Changes in major elements in sediments (Hole 1038A) resembles layer pie, which is a consequence of water-rock interaction under conditions of subhorizontal flows of hydrothermal solutions. Their existence is also support by the location of more strongly altered sediments (Facies $c$ ) in the upper part of the well 1038A and less altered (Facies $b$ ) in lower part.

In Hole $1038 \mathrm{H}$, located in the same place as Hole 1038A, near the active hydrothermal vent with temperature $217^{\circ} \mathrm{C}$ [3], the core section is divided into Units IIc, IIb, Vc, and VIc.

In UnitIIc, the changes in the content of major elements are the same as in the similar layer in Hole 1038A (Table 2).

In Hole $1038 \mathrm{H}$ in Unit $\mathrm{IIb}$, the changes in the chemical composition of the sediments are practically the same as in Unit IIb (Hole 1038A).

Units Vc and VIc are located at the bottom of Hole 1038H. In Unit Vc, the contents of $\mathrm{Si}, \mathrm{Ca}, \mathrm{Na}$ decrease while contents of $\mathrm{K}$ and $\mathrm{Fe}_{\text {total }}$ increase. In Unit VIc the content of $\mathrm{Fe}_{\text {total }}, \mathrm{Mg}$, Ca have increased much stronger than in Unit $\mathrm{Vc}$ at the same time the contents of $\mathrm{Si}, \mathrm{K}$ do not change in contrast to the Unit $\mathrm{Vc}$.

In general, in Hole $1038 \mathrm{H}$, the changes in contents of major elements occur under conditions of the existence of subhorizontal flows of hydrothermal solutions in the same way as in Hole 1038A. It is indicated by the irregular distribution of changes in the contents of major elements in the vertical section of sediments, and resembles a layer pie. The existence of lateral flows of hydrothermal solutions is also showed out in the nature of the distribution changes of hydrothermal solutions in sediments in Hole $1038 \mathrm{H}$. The most strongly altered sediments (Facies $c$ ) are located in its upper and lower parts, in the intervals of $\sim 2-29.80$ and 125.60-192.80 m, while the sediments between them are less altered (Facies $b$ ).

Table 2. Chemical composition of samples from the Hole 1038H.

\begin{tabular}{|c|c|c|c|c|c|c|c|c|}
\hline Sample & $\mathbf{S i}$ & $\mathbf{T i}$ & $\mathbf{F e}_{\text {total }}$ & $\mathbf{M n}$ & $\mathbf{M g}$ & $\mathbf{C a}$ & $\mathbf{N a}$ & $\mathbf{K}$ \\
\hline $2294(\mathrm{IIIc})$ & 25,9 & 1,51 & 7,78 & 1,07 & 2,4 & 1,09 & 1,44 & 1,95 \\
\hline $3086(\mathrm{Vc})$ & 25,1 & 1,37 & 4,99 & 1,08 & 3,06 & 2,30 & 2,40 & 2,39 \\
\hline $3087(\mathrm{Vc})$ & 23,8 & 1,43 & 7,22 & 1,08 & 3,38 & 3,43 & 2,03 & 1,86 \\
\hline $2295(\mathrm{VIc})$ & 21,9 & 1,58 & 11,4 & 1,07 & 2,3 & 3,7 & 1,82 & 1,60 \\
\hline $3085(\mathrm{II})$ & 25,5 & 1,51 & 4,83 & 1,04 & 6,3 & 0,27 & 1,35 & 1,14 \\
\hline $2290(\mathrm{II})$ & 24,6 & 1,55 & 8,69 & 1,10 & 3,9 & 0,25 & 0,53 & 1,45 \\
\hline $2291(\mathrm{IIb})$ & 26,5 & 1,60 & 4,67 & 1,07 & 2,5 & 3,1 & 1,93 & 1,90 \\
\hline $2292(\mathrm{IIb})$ & 27,3 & 1,51 & 5,62 & 1,07 & 2,3 & 2,9 & 1,95 & 1,80 \\
\hline $2293(\mathrm{IIb})$ & 27,2 & 1,54 & 4,64 & 1,07 & 2,4 & 2,7 & 2,41 & 1,82 \\
\hline
\end{tabular}

\section{Conclusions}

In the sediments from Holes $1038 \mathrm{~A}$ and $1038 \mathrm{H}$, drilled directly near the hot springs at Central Hill, Escanaba Trough (Gorda Ridge), the redistribution of major elements occurs during the water-rock interaction. The contents of $\mathrm{Si}, \mathrm{Fe}, \mathrm{Mg}, \mathrm{Ca}, \mathrm{Na}$, and $\mathrm{K}$ have changed in hydrothermally altered sediments. The irregular distribution of major elements in altered 
sediments, resembling a layer pie, reflects the existence of lateral fluxes of hydrothermal solutions. In this process, an increase/decrease in the contents of major elements unaltered sediments shows out a decrease/increase in their contents in solution.

This work was accomplished under the State Program no. 0135-2019-0053. Analytical works were financially supported by the Russian Foundation for Basic Research, project no. 14-05-00153.

Ackonowledgements. We used rock samples taken in the IODP Core Repository (College Station, Texas, Texas A\&M University, United States).

\section{References}

1. T.L. Vallier, P.J. Harold, W.A. Girdley, Provenances and dispersal patterns of turbidite sand in Escanaba Trough, northeastern Pacific Ocean. Mar. Geol., 1, 67-87 (1973)

2. W.R. Normark, C.E. Gutmacher, R.A. Zierenberg, ,F.L. Wong, R.J. Rosenbauer, Sediment fill of Escanaba Trough. In Motron J.L., Zierenberg R.A., Reiss C.A. (Eds.), Geological, Hydrothermal, and Biologic Studies at Escanaba Trough, Gorda Ridge, Offshore Northern California. U.S. Geol. Surv. Bull., 2022, 91-130 (1994)

3. B. Bornhold, J.V. Firth, et al., Proc. ODP, Init.Repts, 169S: College Station, TX (Ocean Drilling Program), 592 (1998)

4. Atwater J.D. Mudie, Detailed near-bottom geophysical study of the Gorda Ridge. J. Geophys. Res., 78, 8665-8683 (1973)

5. J.L. Morton, R.A. Zierenberg, C.A. Reiss, Geologic, hydrothermal, and biologic studies at Escanaba Trough: an introduction. In Morton J.L., Zierenberg R.A., Reiss C.A. (Eds.), Geologic, Hydrothermal, and Biologic Studies at Escanaba Trough, Gorda Ridge, Offshore Northern California. U.S. Geol. Surv. Bull., 2022, 1-18 (1994)

6. R.A. Zierenberg, J.L. Morton, R.A. Koski, C.A. Reiss, Geologic setting of massive sulfide mineralization in the Escanaba Trough. In Morton J.L., Zierenberg R.A., Reiss C.A. (Eds.), Geologic, Hydrothermal, and Biologic Studies at Escanaba Trough, Gorda Ridge, Offshore Northern California. U.S. Geol. Surv. Bull., 2022, 171-197 (1994) 